\title{
Is it relevant to take into account the multipollution context in freshwater radioecology?
}

\author{
J. Garnier-Laplace, A. Boudou', C. Adam, B. Fraysse, O. Ausseil, J.M. Porcher², \\ J.P. Baudin and C. Casellas ${ }^{3}$ \\ Institute of Protection and Nuclear Safety, DPRE/SERLAB, \\ Laboratory of Experimental Radioecology, Cadarache, batiment 186, \\ $B P .13108$ Saint-Paul-lez-Durance cedex, France \\ ${ }^{1}$ Laboratory of Ecophysiology and Ecotoxicology of Aquatic Systems, UMR 5805 du CNRS, \\ Université de Bordeaux 1, Arcachon, France \\ ${ }^{2}$ INERIS, Division for Ecotoxicological Risk Assessment, Verneuil-en-Halatte, France \\ ${ }^{3}$ Division of Environmental Sciences and Public Health, UMR 5556 du CNRS, \\ Université de Montpellier 1, Montpellier, France
}

\begin{abstract}
Should realism of radioecological evaluations be enhanced while taking into account the deleterious influence of stable pollutants on aquatic organisms which can be physiologically stressed, and therefore can modify their response to radionuclide bioaccumulation? Transfer experiments in a multipollution context involved metals (Cd, Zn), organic pollutants (PCBs, PAHs, oestrogenomimetics) and radionuclides (radioactive isotopes of $\mathrm{Co}$, $\mathrm{Cs}$, and Ag). The chosen biological models were a freshwater bivalve (Dreissema polymorpha) and a camivorous fish (Oncorhynchus mykiss). Chronic metallic waterborne exposures (1-4 $\mu \mathrm{g} / \mathrm{L}$. Cd andior $170.250 \mu \mathrm{g} / \mathrm{L} \mathrm{Zn}) \mathrm{led}$ to a decrease in radionuclide bioaccumulation with respect to the reference group ( $\mathrm{Ag}$ and $\mathrm{Cs}$ for fish with respectively $60 \%$ and $-30 \% ; \mathrm{Co}$ for bivalve with $-50 \%$, on average); while no effect was noticed with other radionuclide/organism pairs (Co for fish, $\mathrm{Cs}$ and $\mathrm{Ag}$ for bivalve). Prior exposure to organic micropollutants enhanced ${ }^{57} \mathrm{Co}$ and ${ }^{134} \mathrm{Cs}$ uptake kinetic parameters from water and retention time in fish; the radionuclide contamination levels of exposed groups were always higher than those obtained from the reference groups $(+10 \%$ to $+60 \%$ as a function of the organic micropollutant). Some explanations are given for these first results that underline the relevancy of this new research field.
\end{abstract}

\section{INTRODUCTION AND GENERAL SCOPE}

Until now, the basic approach in radioccology tended to analyse and model knowledge conceming radionuclide transfers within the different abiotic and biotic components of aquatic ecosystems, without considering non-radjoactive contaminants. However, human activities result in the dispersal of a range of pollutants as trace elements in the environment and the multipollution context therefore becomes more and more pertinent. Nevertheless, the possible synergy or inhibition of radionuclide uptake and depuration processes by living organisms in conjunction with other pollutants are totally ignored. In order to fill up this knowledge gap and determine the relevancy of considering the influence of mutipollution in radioecological assessment models, the question of whether a prior and/or a concomitant exposure to stable toxicants modifics radionuclides' bioaccumulation characteristics must be addressed. How do these stable xenobjotics, which can induce stress or alter the organism's physiology, act and/or interact on the behaviour of radionuclides within biological systems? The effect of disturbances due to these xenobiotics on radionuclides bioaccumulation has never been dealt with by the freshwater radioecologist community. This paper, illustrated by some selected results, summarises the main lessons learnt from a wider research programme carried out both in laboratory under controlled conditions and in more complex in situ situations. In front of the increasing number of non-radioactive pollutants potentially present in freshwaters, the strategic approach consisted in selecting a few number of "model pollutants" in order to represent metals ( $\mathrm{Cd}, \mathrm{Zn}$ ) and four main categories of organic pollutants (PAH: benzo(a)pyrene and fluoranthene; PCB: Arochlor 1242 and PCB 77; herbicides: atrazine; and oestrogenomimetics: 17- $\beta$ oestradiol. The selected radionuclides were representative of the low-level radioactive liquid wastes from nuclear power plants which are discharged into the environment in a discontinuous manner. Their relative composition is fairly constant: ${ }^{58} \mathrm{Co},{ }^{60} \mathrm{Co},{ }^{110 \mathrm{~m}} \mathrm{Ag},{ }^{134} \mathrm{Cs}$ and ${ }^{637} \mathrm{Cs}$ are among the common $\beta / \gamma$ emitting radionuclides discharged under normal operating conditions. The radioisotopes of silver, cobalt and caesium are therefore of major radioecological importance and their transfer to the various compartments of freshwater ecosystems has been the subject of numerous studies. This very broad research field was 
initially focused by selecting two biological models: a bivalve, the zebra mussel (Dreissena polymorpha) and a carnivorous fish, the rainbow trout (Oncorhynchus mykiss). These species have been extensively used for biomonitoring programmes in ecotoxicology $[1,2]$ and in radioecology $[3,4]$; but also for toxicity tests $[5,6]$.

\section{MATERIAL AND METHODS}

\subsection{Experimental strategy and global overview of design for assay conditions}

All experiments were designed in such a way to simulate the radioactive liquid release by a nuclear plant into a freshwater ecosystem chronically contaminated with stable pollutants. A generic scheme was applied and adapted to: (1) the selected biological models; (2) the selected stable pollutants (type and exposure concentration) alone or in combination; and (3) the set of conditions for abiotic variables. This experimental design was based on three phases:

- a prior-exposure phase (phase I) in which organisms were exposed to a stable pollutant alone. At the end of this phase, several biochemical responses, adapted to the biological model and the nature of the stable pollutant, were measured in selected tissues to assess the early stress effects at cellular or subcellular level: reactions to oxidative stress (enzymatic activities playing a major role in the oxidation prevention: catalase, superoxide dismutase, glutathione reductase and peroxydase, forms of glutathione, ...), energy expenditure (adenylate load, glycogen reserves and the protein, lipid and glucid content), disruption of ion homeostasis $(\mathrm{Na}, \mathrm{K}, \mathrm{Cl})$, induction of proteins such as metallothioneins, stress proteins (hsp)...;

- a subsequent-exposure phase (phase If) in which organisms were exposed to waterborne radionuclides in addition to the other stable pollutant;

- the final phase (phase III) in which the radionuclide depuration was studied under the same conditions as in the pre-exposure phase.

For each biological model, one group of organisms for each stable pollutant exposure condition and one reference group (not exposed to stable pollutant) were constituted and properly acclimatised to the experimental conditions. During phase II, each group of organisms (reference and exposed) was contaminated by the addition of radionuclides as ${ }^{110 \mathrm{~m}} \mathrm{AgNO}_{3},{ }^{57} \mathrm{CoCl}_{2}$ and ${ }^{134} \mathrm{CsCl}$ solutions obtained from the Amersham International Radiochemical Center (UK). Throughout the experiments, abiotic factors such as water physical and chemical characteristics were monitored and maintained constant.

For metal exposure conditions, the four groups of bivalve and fish were contaminated from water ( $\mathrm{Cd}$ and/or $\mathrm{Zn}$ added in the form of dichloride). Concerning organic micropollutants, six groups of fish were contaminated by an intra-peritoneal injection of one organic compound while the reference group received an injection of an excipient (com-oil).

\subsection{Sampling, chemical, biochemical and radioactive analyses}

Throughout all metal-exposure experiments, raw water samples were taken every day and analysed for $\mathrm{Cd}$ and $\mathrm{Zn}$ concentrations, and other physical and chemical parameters (major ions, $\mathrm{pH}$, conductivity, dissolved $\mathrm{O}_{2}$ ). For all experiments, concentrations of radionuclides in the water were monitored daily during phase II in $50 \mathrm{ml}$ samples. In order to measure the metal content in the organisms, dissections were carried out at regular time intervals and each organ or tissue was mineralised individually $\left(\mathrm{HNO}_{3} 65 \%, 3\right.$ hours, $105^{\circ} \mathrm{C}$, Blockdigest). $\mathrm{Cd}$ and $\mathrm{Zn}$ concentrations were determined in each sample. For fish, exposure to organic micropollutant was checked by specific biomarker measurement (EROD activity for PCBs, FACs for PAHs, vitellogenin induction for oestradiol). All other biomarkers were measured by traditional methods $[7,8]$. The $\mathrm{Cd}$ content was determined by graphite furnace atomic absorption spectrometry (Perkin Elmer $4110 \mathrm{ZL}$; Detection Limit of $0.1 \mu \mathrm{g} / \mathrm{L}$ ). Zn concentrations were determined by flame atomic absorption spectrometry (Varian, Spectro AA 200; DL of $10 \mu \mathrm{g} / \mathrm{L}$ ).

During phases $I I$ and III, the radioactivity of 8 to 15 individuals was daily estimated by whole-body counts of $\gamma$ emissions for two minutes. Radioactivity measurements were performed with a single-channel 
analyser connected to a thallium-activated sodium iodide well probe. At different sampling times, radioactivity measurements were also performed on mineralised organs/tissues compartments, to assess radionuclide distribution within the organisms. The measurements were performed using a high-purity germanium detector connected to a multichannel analyser.

\subsection{Processing of experimental data}

The method used to determine the main characteristics of the radionuclides' bioaccumulation by the organisms is based on the utilisation of mono-compartimental kinetic models [9], describing under a number of assumptions, the pattern of change in the concentration of a radionuclide in the whole-body organism by the following first order differential equation:

$$
\frac{d C_{T}}{d t}=u \times C_{w}-(d+G) \times C_{T}
$$

where $C_{T}$ is the radionuclide concentration in the whole-body organism $\left(\mathrm{Bq} \mathrm{g}^{-1}\right), t$ is the time of exposure (days), $u$ and $d$ are the uptake and depuration kinetic rates respectively $\left(\mathrm{d}^{-1}\right), C_{w}$ the radionuclide concentration in the water $\left.(\mathrm{Bq} \mathrm{ml})^{-1}\right)$ and $G$ the individual growth rate $\left(\mathrm{d}^{-1}\right)$. The kinetic parameters were estimated by numerical calculation (method of Runge-Kutta of the order 4) using the computer program ModelMaker 3.0 (Cherwell Scientific). The assessment of the interactions of radionuclides with stable pollutant was carried out using ANOVA to test for significant differences between reference and stable pollutant-exposed groups for three endpoints: uptake and depuration kinetic rates, contamination level at a given time and tissue distribution of the radionuclide. Statistical analyses were performed using the SYSTAT software for windows, version 5 (Systat Institute, Evanston, Illinois Deltasoft), and an effect was considered as significant for $\alpha \leq 0.05$.

\section{RESULTS AND DISCUSSION}

\subsection{Interactions between metals and radionuclides (Table I)}

\subsubsection{Metal induced stress in fish and bivalve}

$\mathrm{Cd}$ and/or $\mathrm{Zn}$ concentrations in water used in all metal-exposed experiments were lower or very close to guideline standards for surface water intended for the production of drinking water i.e. $1 \mu \mathrm{g} \mathrm{Cd} / \mathrm{L}$ and 500 $\mu \mathrm{g} \mathrm{Zn} / \mathrm{L}$. In these conditions, organisms are able to regulate their internal concentrations for zinc ( $7 \mu \mathrm{g} / \mathrm{g}_{\text {gnuscle }} \mathrm{w} . \mathrm{w}$. for fish, $30 \mu \mathrm{g} / \mathrm{g}_{\text {soft tissue }} \mathrm{w} . \mathrm{w}$. for bivalve). Cadmium concentrations in the organisms indicated a significant accumulation of the metal. For fish, muscles remained the less contaminated tissue (non detectable after a four-week exposure period). For bivalve, a quasi-linear increase of Cd concentrations in soft tissues was observed, reaching $1.5 \mu \mathrm{g} / \mathrm{g}$ after 4 weeks. Measurements of biomarkers in fish indicate that cadmium causes disruptions at the metabolism level as a whole and on the ionic balance regulation of the organism without however resulting in the development of pathologies (no modification in plasmatic enzymatic activities, no induction of stress proteins, no significant disturbance of plasmatic lipid, glucid, and protein concentrations). For both biological models, biomarkers indicated a moderate stress compensated by defense mechanisms that are solicited in order to (I) reduce the cellular toxicity of $\mathrm{Cd}$ and/or regulate the internal concentration of $\mathrm{Zn}$ (synthesis of metallothioneins), and (2) react against oxidative stress (disturbance of the glutathione status with increase of the total and reduced forms, induction of the SOD activity). These protection systems seamed to be sufficient to avoid deep metabolic disequilibrium.

\subsubsection{Patterns of interactions and possible underlying mechanisms}

3.1.2.1 ${ }^{134} \mathrm{Cs}$ or ${ }^{110 \mathrm{~m}} \mathrm{Ag}$ : For bivalve, no effect was evidenced concerning ${ }^{134} \mathrm{Cs}$ or ${ }^{110 \mathrm{~m}} \mathrm{Ag}$. However, a clear variation in the soft tissue contribution to the total radioactivity of the organism was observed for ${ }^{110 \mathrm{~m}} \mathrm{Ag}$. For fish, $\mathrm{Cd}$ and/or $\mathrm{Zn}$ exposure induced a significant reduction of the accumulation levels and 
uptake rates of ${ }^{110 m} \mathrm{Ag}$ (by $-60 \%$ ) and to a lesser extent for ${ }^{134} \mathrm{Cs}$ (by $-30 \%$ ). For both radionuclides, uptake rates were reduced and the trend for the residence time was to increase. The two radionuclides belong to categories of elements with totally different biochemical behaviours: caesium is a biochemical analogous macro-nutrient of potassium, while silver is a toxic element. Therefore the net decrease in their biokinetics could be accounted for in a variety of ways due to the multitude of processes likely to be solicited in response to a cadmium and/or zinc exposure. Mechanisms of cellular protection activated due to pre-exposure to stable metals may modify fluxes from and to the cells. Exposure to heavy metals induces an increase in concentrations of metallothioneins and total glutathione which both play an important role in the sequestration of metallic ions but also in their transport and excretion [10, 11$]$. Exposure to metals may also induce a decrease in metabolism, such as a reduction in respiration, which results in reduced efficiency of uptake routes of pollutants. For example, $\mathrm{Cu}$ exposure may result in a reduction of the respiratory activity in fish [12]. $\mathrm{Zn}$ exposure is known to reduce filtration rate for Dreissena (NOEC of $190 \mu \mathrm{g} / \mathrm{L}$ [13]). The volume of water filtered by the gills and therefore the quantity of radionuclides is reduced. The increased production of mucus acting as a metal trap $[14,15]$ may also be linked to this phenomenon. Finally, Cd exposure can modify the selective permeability properties of the gills, by interference with the calcium pumps [16] as well as the basal $\mathrm{Mg}^{2+}$-ATPase activity and the $\mathrm{Na}^{+} / \mathrm{K}^{+}$-ATPase activity $[17,18]$.

Table I. Radionuclide bioaccumulation characteristics for the two biological models and the different metal condition groups. $u$ and $d$ represent the uptake and depuration kinetic rates, respectively. $C_{T}$ is the modelled radionuclide concentration in the whole organism (shell + soft body for the bivalves) for $C_{w}=1 \mathrm{~Bq} / \mathrm{mL}$ after a 20 -day exposure period. $\mathrm{RC}_{\text {tissue }}$ is the relative contribution of the radionuclide in the specified tissuc (soft tissues and skeletal muscles respectively for bivalve and fish) to the total quantity in the organism (dimensionless). $\Delta_{\text {ref }}$ is the percentage of variation from the corresponding value obtained for the reference group. This parameter was only calculated for significant statistical difference between the two groups (ANOVA with 2 factors, on whole time data series).

\begin{tabular}{|c|c|c|c|c|c|c|c|c|c|}
\hline \multirow[t]{2}{*}{ Radionuclide } & \multirow{2}{*}{$\begin{array}{l}\text { Exposure } \\
\text { Condition' }\end{array}$} & \multicolumn{4}{|c|}{ Bivalve (Dreissena polymorpha) } & \multicolumn{4}{|c|}{ Fish (Oncorhynchus mykiss) } \\
\hline & & $\begin{array}{l}u \pm \text { A.S.E. } \\
\mathrm{ml} \mathrm{g}^{-1} \text { day- }\end{array}$ & $\begin{array}{c}d \pm \text { A.S.E. } \\
\text { day }^{-1}\end{array}$ & $\begin{array}{c}C_{r}\left(\hat{\left.R C_{\text {nissuer }}\right)}\right. \\
\mathbf{B q ~}^{-1}\end{array}$ & $\begin{array}{l}\Delta_{\text {ref }} \\
\%\end{array}$ & $\begin{array}{c}u \pm \mathrm{SD} \\
\mathrm{ml} \mathrm{g}^{-1} \mathrm{day}^{-1}\end{array}$ & $\begin{array}{c}d \pm \mathrm{SD} \\
\text { day }^{-1}\end{array}$ & $\begin{array}{c}C_{T}\left(R C_{\text {ricreds }}\right. \\
\mathrm{Bq} \mathrm{g}^{-t}\end{array}$ & $\begin{array}{c}\Delta \Delta_{\text {ref }} \\
\%\end{array}$ \\
\hline \multirow[t]{4}{*}{${ }^{57} \mathrm{Co}$} & Reference & $22 \pm 0.48$ & $0.020 \pm 0.003$ & $366(2.0 \%)$ & _ & $0.21 \pm 0.016$ & $0.093 \pm 0.032$ & $1.9(4 \%)$ & - \\
\hline & $\mathrm{Cd}$ & $23 \pm 0.44$ & $0.021 \pm 0.003$ & $37 t(1.7 \%)$ & -14 & $0.23 \pm 0.020$ & $0.097 \pm 0.022$ & $2.0(4 \%)$ & _- \\
\hline & $\mathbf{Z n}_{\mathbf{n}}$ & $15 \pm 0.44$ & $0.025 \pm 0.005$ & $238(1.9 \%)$ & -39 & $0.25 \pm 0.037$ & $0.083 \pm 0.011$ & $2.4(4 \%)$ & - \\
\hline & $\mathrm{Zn} / \mathrm{Cd}=$ & $15 \pm 0.39$ & $0.024 \pm 0.004$ & $245(1.6 \%)$ & -47 & $0.19 \pm 0.020$ & $0.11 \pm 0.015$ & $1.5(4 \%)$ & - \\
\hline \multirow[t]{4}{*}{${ }^{1100 \pi} \mathrm{Ag}$} & Reference & $62 \pm 4.0$ & $0.032 \pm 0.010$ & $917(14 \%)$ & - & $0.89 \pm 0.078$ & $0.032 \pm 0.011$ & $13(2 \%)$ & - \\
\hline & Co & $66 \pm 3.7$ & $0.055 \pm 0.010$ & $801(38 \%)$ & - & $0.46 \pm 0.089$ & $0.043 \pm 0.029$ & $6.2(2 \%)$ & -53 \\
\hline & $\mathbf{Z n}$ & $72 \pm 6.5$ & $0.064 \pm 0.015$ & $816(40 \%)$ & - & $0.48 \pm 0.070$ & $0.027 \pm 0.019$ & $7.4(2 \%)$ & -44 \\
\hline & $\mathrm{Zn} / \mathrm{Cd}$ & $101 \pm 6.9$ & $0.065 \pm 0.011$ & $112(23 \%)$ & - & $0.40 \pm 0.030$ & $0.048 \pm 0.011$ & $5.1(2 \%)$ & -61 \\
\hline \multirow[t]{4}{*}{${ }^{134} \mathrm{Cs}$} & Reference & $2.5 \pm 0.20$ & $0.14 \pm 0.019$ & $16.5(20 \%)$ & - & $0.16 \pm 0.004$ & $0.038 \pm 0.008$ & $2.2(46 \%)$ & - \\
\hline & $\mathrm{Cd}$ & $2.9 \pm 0.17$ & $0.15 \pm 0.014$ & $18.5(24 \%)$ & - & $0.12 \pm 0.004$ & $0.045 \pm 0.009$ & $1.6(47 \%)$ & -29 \\
\hline & $Z_{n}$ & $2.6 \pm 0.14$ & $0.13 \pm 0.012$ & $18.5(25 \%)$ & - & $0.13 \pm 0.003$ & $0.041 \pm 0.012$ & $1.8(45 \%)$ & -21 \\
\hline & $\mathrm{Zn} / \mathrm{Cd}$ & $2.6 \pm 0.16$ & $0.12 \pm 0.013$ & $18.9(15 \%)$ & _- & $0.13 \pm 0.004$ & $0.043 \pm 0.014$ & $1.7(46 \%)$ & -22 \\
\hline
\end{tabular}

1 Metal exposure conditions were as followed: Reference group -ro addition of $\mathrm{Cd}$ or $\mathrm{Zn}$, Cd goup -4 and $\mathrm{t} \mu \mathrm{g} / \mathrm{L}$. $\mathrm{Cd}$ respectively for bivalve and fish; $\mathrm{Zn}$ group - 250 and $170 \mu \mathrm{g} / \mathrm{L}$ for bivalve and fish; $\mathrm{Zv} / \mathrm{Cd}$ group - simuitaneous contamination with the mentioned concentrations for $\mathrm{Cd}$ and $\mathrm{Zn}$.

3.1.2.2 ${ }^{57} \mathrm{Co}$ : For this radionuclide, no detectable effect was evidenced for fish. For bivalve, the levels of ${ }^{57} \mathrm{Co}$ accumulation was markedly altered by the presence of $\mathrm{Cd}$ and $\mathrm{Zn}$, with a clear evidence of the inhibiting effect of $\mathrm{Zn}$ on the uptake rate of this radionuclide. Characterised by very similar biochemical properties, ${ }^{57} \mathrm{Co}$ follows the $\mathrm{Zn}$ metabolic pathway. For $D$. polymorpha, our results show that this analogy of biological behaviour induced (1) a net decrease in ${ }^{57} \mathrm{Co}$ input through biological barriers, (2) a cellular redistribution of ${ }^{57} \mathrm{Co}$, marked by a decrease of the dissolved pool in the cytosolic fraction and an increase of the storage in the form of mineral granules ( $\mathrm{Ca}$ phosphates and pyrophosphates), (3) a modification of the Co tissue distribution with a storage in the form of granular deposits in the mantle and the excretory 
organs [8]. These biomineralisation processes in bivalves play a fundamental role and could explain the marked difference of effect between the two biological models.

\subsection{Interactions between organic micropollutant and radionuclides (Table II)}

\subsubsection{Organic pollutant induced stress in fish}

The results of the biochemical analyses have shown that intraperitoneal injection of organic pollutants led to metabolic disturbances in the trout, particularly in connection with a global decrease of antioxidative defence (decrease of all glutathione forms and SOD; increase of GPx activity). Disturbances within energetic metabolism were also revealed.

\subsubsection{Patterns of interactions and possible underlying mechanisms}

A significant increase of ${ }^{57} \mathrm{Co}$ and ${ }^{134} \mathrm{Cs}$ bioaccumulation was observed with the six organic pollutants studied, respectively ranging from 30 to $60 \%$ and from 15 to $45 \%$. These interactions resulted from an increase in uptake rates and a varying reduction in excretion rates. For ${ }^{110 \mathrm{~m}} \mathrm{Ag}$ and the two tested organic pollutants, intra-peritoneal injections caused an increase in radionuclide concentrations in the whole fish. As for metal/radionuclide interactions, several assumptions can be suggested: an increase in respiratory activity by alteration of the global metabolism, a decrease in the $\mathrm{Na}^{+} / \mathrm{K}^{+}$-ATPase in gills and therefore modification of the ionic flux, or an alteration of the epithelium permeability [7].

Table II. Fish radionuclide bioaccumulation characteristics for the different organic micropollutant condition groups. $u$ and $d$ represent the uptake and depuration kinetic rates respectively. $C_{T}$ is the modelled radionuclide concentration in the whole-body organism for $C_{w}=1 \mathrm{~Bq} / \mathrm{mL}$ after a 20 -day exposure period. $R C_{\text {muscle }}$ is the relative contribution of the radionuclide in the muscles to the total quantity in the organism (dimensionless). $\Delta_{\text {ref }}$ is the percentage of variation from the correspondirg value obtained for the control group. This parameter was only calculated for significant statistical difference between the two groups (ANOVA with 2 factors, on whole data series).

\begin{tabular}{|c|c|c|c|c|c|}
\hline Radionuclide & $\begin{array}{l}\text { Exposure } \\
\text { condition' }\end{array}$ & $\begin{array}{l}u \pm \text { A.S.E. } \\
\mathrm{ml} \mathrm{g}^{-1} \text { day }^{-1}\end{array}$ & $\begin{array}{c}d \pm \text { A.S.E. } \\
\text { day }\end{array}$ & $\begin{array}{c}C_{\mathrm{T}}\left(R C_{\text {masele }}\right) \\
\mathrm{Bq} \mathrm{g}^{\cdot 1}\end{array}$ & $\begin{array}{c}A_{\text {ref }} \\
\%\end{array}$ \\
\hline \multirow[t]{7}{*}{${ }^{57} \mathrm{Co}$} & Reference & $0.24 \pm 0.02$ & $0.12 \pm 0.020$ & $1.8(6.1 \%)$ & - \\
\hline & 17- $\beta$-estradiol & $0.42 \pm 0.04$ & $0.17 \pm 0.022$ & $2.4(4.7 \%)$ & +31 \\
\hline & Arochlor 1242 & $0.28 \pm 0.02$ & $0.08 \pm 0.008$ & $2.8(5.6 \%)$ & +54 \\
\hline & PCB 77 & $0.28 \pm 0.02$ & $0.10 \pm 0.010$ & $2.4(5.7 \%)$ & +33 \\
\hline & Benzo(a)pyrene & $0.31 \pm 0.03$ & $0.09 \pm 0.010$ & $2.9(6.2 \%)$ & +58 \\
\hline & Fluoranthene & $0.32 \pm 0.04$ & $0.15 \pm 0.020$ & $2.0(7.0 \%)$ & +11 \\
\hline & Atrazine & $0.30 \pm 0.02$ & $0.11 \pm 0.010$ & $2.4(5.2 \%)$ & +33 \\
\hline \multirow[t]{3}{*}{${ }^{110 n} \mathrm{Ag}^{2}$} & Reference & $0.97 \pm 0.11$ & $0.038 \pm 0.011$ & $13(1 \%)$ & - \\
\hline & 17- $\beta$-estradiol & $1.45 \pm 0.19$ & $0.059 \pm 0.011$ & $17(2 \%)$ & +25 \\
\hline & $\mathrm{PCB} 77$ & $0.85 \pm 0.16$ & $0.033 \pm 0.041$ & $12(2 \%)$ & - \\
\hline \multirow[t]{7}{*}{${ }^{134} \mathrm{Cs}$} & Reference & $0.067 \pm 0.004$ & $0.038 \pm 0.006$ & $0.94(30 \%)$ & - \\
\hline & $17-\beta$-estradiol & $0.076 \pm 0.004$ & $0.030 \pm 0.004$ & $1.14(28 \%)$ & +22 \\
\hline & Arochlor 1242 & $0.075 \pm 0.003$ & $0.0029 \pm 0.004$ & $1.14(34 \%)$ & +22 \\
\hline & $\mathrm{PCB} 77$ & $0.091 \pm 0.004$ & $0.033 \pm 0.004$ & $1.33(31 \%)$ & +42 \\
\hline & Benzo(a)pyrene & $0.081 \pm 0.005$ & $0.0034 \pm 0.005$ & $1.18(33 \%)$ & +25 \\
\hline & Fluoranthene & $0.078 \pm 0.004$ & $0.036 \pm 0.004$ & $1.11(39 \%)$ & +18 \\
\hline & Atrazine & $0.089 \pm 0.003$ & $0.037 \pm 0.003$ & $1.26(32 \%)$ & +34 \\
\hline
\end{tabular}




\section{CONCLUSION AND PERSPECTIVES}

Globally, the interactions between stable pollutant(s) and radionuclide(s) are case-specific with respect to the biological model and to the biochemical properties of the studied chemical elements. To provide a rational basis for extrapolation between species and radionuclides, several research topics will be investigated: (1) to understand and quantify the links between the stable pollutant-induced stress in organisms (especially biomarkers of oxidative stress and protein synthesis) and the modification of the radionuclide bioaccumulation endpoints, (2) to provide evidence of the mechanisms involved for each chemical element alone, to understand how they can interfere when they are in combination. Moreover, two main questions still remain: from which concentration levels of stable pollutants in the environment will a modification of radionuclide bioaccumulation occur? Should interactions be the same in the case of radionuclide long term exposures (i.e. significant in terms of life span of organisms)? Under chronic exposure conditions, radionuclides in the environment (external irradiation) and/or within organisms (intemal irradiation) may induce biological effects. In a multipollution context, these effects, very poorly known until now, may be exacerbated or reduced as a function of the potential action or interaction of all the poliutants occurring simultaneously. These combined effects may be the result of the similarity of the metabolic pathways taken by the considered pollutants, or of the physiological state of the organism in relation with the efficiency of the detoxification processes likely to be solicited by one or several pollutants. All this knowledge will make improvements to operational radioecological assessment models in order to obtain a satisfactory confidence level in calculated predictions while including (1) other stressors such as the presence of other classes of pollutants than radionuclides; (2) the variations of the physico-chemical characteristics of the aquatic biotopes (temperature, $\mathrm{pH}$, dissolved oxygen concentration, ...), acting simultaneously on the pollutant bioavailability and on the physiological functions of the organisms; (3) the trophic route of exposure, via contaminated prey ingestion.

\section{References}

[1] Phillips, D.J.H., Environ. Pollut. 13 (1977) 281-317.

[2] Mersch, J. and Pihan, J.C., Arch. Environ. Contam. Toxicol. 25 (1993) 353-364.

[3] Kinney, R.M., Manos, C.G. and Mills, E.L., Chemosphere 28 (1994) 729-735.

[4] Garnier-Laplace, J., Vray, F., Baudin, J.P. and Jourd'heuil, L., Can. J. Fish. Aquat. Sci. 55 (1998) $999-$ 1009 .

[5] Wang, W.X. and Fisher, N.S., Environ. Toxicol. Chem. 18 (1999) 2034-2045.

[6] Paquin, P.R., Santore, R.C., Wu, K.B., Kavvadas, C.D. and Di Toro, D.M., Environ. Sci. Policy 3 (2000) $\mathbf{S 1 7 5 - S 1 8 2 .}$

[7] Ausseil, O., Doct. thesis, University of Provence (2001) 238 p..

[8] Fraysse, B., Doct. thesis, University of Bordeaux I (2001) 142 p..

[9] Garnier-Laplace, J., Vray, F. and Baudin, J.P., Wat. Air Soil Pollut. 98 (1997) 141-166.

[10] Kito, H., Tazawa, T., Ose, Y., Sato, T. and Ishikawa, T., Comp. Biochem. Physiol. 73C (1982) 135139.

[11] Foulkes, E., Life Sci. 52 (1993) 1617-1620.

[12] De Boeck, G., De Smet, H. and Blust, R., Aquat. Toxicol. 32 (1995) 127-141.

[13] Kraak, M.H.S., Stuijfzand, S.C., Buckert-De Long, M.C., De Groot, C.J. and Admiraal, W., Aquat. Toxicol. 30 (1994) 77-89.

[14] Coello, W. and Khan, M., Arch. Environ. Contam. Toxicol. 30 (1996) 319-326.

[15] Maarouf, A., Doct. thesis, University of Metz (1988) 214 p..

[16] Verbost, P., Van Rooij, J., Flik, G., Lock, R. and Wendelaar Bonga., S., J. Exp. Biol 145 (1989) 185-197.

[17] Lemaire-Gony, S. and Mayer-Gostan, N., Ecotoxicol. Environ. Saf. 28 (1994) 43-52.

[18] Viarengo, A., Mancinelli, G., Pertica, M., Fabbri, R. and Orunescu, M., Comp., Biochem. Physiol. $106 C$ (1993) 655-660.

[19] Viarengo, A., Aquat. Sci. 1 (1989) 295-317. 